\title{
Amyloid fibril formation is progressive and correlates with beta-cell secretion in transgenic mouse isolated islets
}

\author{
D.L.A. MacArthur ${ }^{1}$, E.J.P. de Koning ${ }^{1}$, J.S.Verbeek ${ }^{2}$, J.F. Morris ${ }^{1}$, A.Clark ${ }^{3}$ \\ ${ }^{1}$ Department of Human Anatomy and Genetics, University of Oxford, UK \\ ${ }^{2}$ Department of Immunology, University Hospital Medical School, Utrecht, The Netherlands \\ ${ }^{3}$ Diabetes Research Laboratories, Radcliffe Infirmary, Oxford, UK
}

\section{Abstract}

Aims/hypothesis. Amyloid fibrils are formed in islets isolated from transgenic mice expressing the gene for human islet amyloid polypeptide (IAPP) by an unknown mechanism. This model of islet amyloidosis in Type II (non-insulin-dependent) diabetes mellitus has been used to investigate the temporal and glucose dependency of fibril formation.

Methods. To determine the time course and nature of amyloid-like accumulations and the role of glucose, transgenic mouse islets were cultured for $2-12$ days in medium containing glucose $(4.2 \mathrm{mmol} / \mathrm{l}$, $11.1 \mathrm{mmol} / \mathrm{l}$ or $16.7 \mathrm{mmol} / \mathrm{l})$ or $3.3 \mathrm{mmol} / \mathrm{l}$ glucose plus non-glucose secretagogues, $10 \mathrm{mmol} / \mathrm{l}$ leucine, $10 \mathrm{mmol} / \mathrm{l}$ leucine $+0.1 \mathrm{mmol} / \mathrm{l}$ tolbutamide, $10 \mathrm{mmol} / \mathrm{l}$ alpha-ketoisocaproic acid $+10 \mathrm{mmol} / \mathrm{l}$ glutamine. The extent of fibril formation was determined by quantitative immuno-electron microscopy. Insulin and islet amyloid polypeptide secretion into the media was measured by radioimmunoassay.

Results. Extracellular amyloid fibrils immunoreactive for islet amyloid polypeptide were visible initially af- ter 6 days of culture in $11.1 \mathrm{mmol} / \mathrm{l}$ glucose and formed $2.3 \pm 0.8 \%$ of the islet area after 12 days; small accumulations of intracellular fibrils and amorphous extracellular islet amyloid polypeptide-immunoreactive material were present at 6-12 days. Beta-cell secretion was increased significantly by $16.7 \mathrm{mmol} / \mathrm{l}$ glucose and by alpha-ketoisocaproic acid + glutamine. The proportion of fibrillar amyloid (amyloid area/islet area $\%$ ) correlated with the amount of insulin $(r=0.55, p<0.05)$ and IAPP $(r=0.5, p<0.05)$ in the culture media. Evidence of cellular damage was present in less than $10 \%$ cells and correlated with the degree of fibril deposition $(r=0.8, p<0.0001)$.

Conclusion/interpretation. These data suggest that islet amyloid polypeptide amyloid is formed primarily at extracellular sites in isolated transgenic mouse islets and progressive fibril formation correlates with beta-cell secretion. [Diabetologia (1999) 42: 12191227]

Keywords Islet amyloid polypeptide (IAPP), amylin, amyloid, fibrils, islets, transgenic mice, glucose, betacell secretagogues.
Amyloid deposits are found in the islets of Langerhans of up to $96 \%$ of patients with Type II (non-insulin-dependent) diabetes mellitus $[1,2]$ but the rela-

Received: 11 March 1999 and in revised form: 21 May 1999

Corresponding author: Dr A. Clark, Diabetes Research Laboratories, Radcliffe Infirmary, Woodstock Rd, Oxford, OX2 $6 \mathrm{HE}, \mathrm{UK}$

Abbreviations: IAPP, Islet amyloid polypeptide; TM, transgenic mice; hIAPP, human islet amyloid polypeptide; EA, egg albumen. tion of islet amyloid to the syndrome of diabetes is not clear. Amyloid deposition precedes the onset of hyperglycaemia in cats and monkeys $[3,4]$ suggesting a primary aetiological role of amyloid in these species. The severity of islet amyloidosis in diabetic patients at autopsy is, however, greatest in those who have progressed from sulphonylurea to insulin treatment [5] and the degree of amyloid deposition is associated with a decrease of beta-cell function in monkeys [4] implicating islet amyloid in islet dysfunction in the later stages of the disease. An increased incidence of amyloid deposition in vivo in some strains 
of transgenic mice expressing the gene for human islet amyloid polypeptide (hIAPP) is associated with a substantial decrease in the mass of islet beta-cells and an increased frequency of hyperglycaemia [6, 7, $8,9]$. This could be explained by the proposed cytotoxic role of amyloid: fibrils formed from human synthetic islet amyloid polypeptide (IAPP) have been shown to be cytotoxic to pancreatic islet cells in vitro [10].

Islet amyloid polypeptide, (amylin) is the major component of the insoluble pancreatic amyloid fibrils present in Type II diabetes [11, 12]. It is a normally soluble 37-amino-acid peptide synthesised in betacells, co-localised with insulin in beta-cell granules [13] and co-secreted in response to beta-cell secretagogues $[14,15]$. Islet amyloid that is associated with diabetes is found in man, monkeys and cats but not in rats or mice [16]. This is related to species-specific variations in the primary sequence of IAPP, particularly in amino acids IAPP ${ }_{25-29}$ which have been shown to be important for amyloid fibril formation [17]. The amino acid sequence cannot, however, be the sole determining factor for amyloid fibril formation because most non-diabetic humans, cats and monkeys do not develop islet amyloid [16, 18, 19]. The mechanisms by which soluble monomeric human IAPP is converted into insoluble amyloid fibrils in diabetes have yet to be explained.

Amyloid deposits form spontaneously in vivo in some, but not all, strains of transgenic mice (TM) expressing the $h I A P P$ gene; IAPP amyloid has been identified in inbred "homozygous" hIAPP TM [6] and in "heterozygous" hIAPP TM treated with growth hormone and dexamethazone [8]. In addition amyloid deposition was associated with obesity and hyperglycaemia in hIAPP TM when fed a high fat diet [9] in cross-bred obese agouti mice or TM expressing the $o b$ gene $[7,20]$. The causal factors for formation of fibrils from IAPP are not, however, explained in these mouse models; obesity and the associated hypersecretion from islets is implicated and, although an intracellular origin of fibrils has been proposed [8], these hypotheses remain to be proven. The Utrecht/Oxford strain of hIAPP TM do not form amyloid fibrils in vivo but IAPP-immunoreactive fibrils are formed in vitro when their isolated islets are cultured for several days in medium containing high glucose concentrations $[21,22]$. This is a good model to determine the effects on the degree of IAPP fibril formation of specific factors which modulate beta-cell secretion or interact with secretory products and to identify the site of fibril formation. Islets isolated from hIAPP TM were cultured for 2-12 days in different conditions of glucose and nonglucose beta-cell secretagogues to establish the time course and nature of IAPP fibrillar and non-fibrillar accumulations. The requirement for increased extracellular glucose on IAPP fibrillogenesis and the de- gree of amyloid formation as well as the effects of the fibrils on islet cell viability were assessed by quantitative immunoelectron microscopy.

\section{Materials and methods}

Islet isolation, culture and tissue processing. Islets were studied from transgenic mice (age: > three months; sex: male and female; original source: Department of Immunology, University Medical Centre, Utrecht, The Netherlands) expressing the gene for hIAPP under transcriptional control of a rat insulin 2 gene promoter [22] and from non-transgenic litter mates. This work was approved by the UK Home Office and animal care followed the 'Principles of Laboratory Animal Care' (NIH publication No 85-23 revised 1985). Transgene incorporation was confirmed by Southern blotting of chromosomal DNA extracted from tail biopsies as described previously [23]. The pancreas was removed from animals killed by cervical dislocation, and digested with collagenase. Islets were handpicked and maintained free-floating in tissue culture in RPMI 1640 medium containing $10 \%$ (v/v) fetal calf serum, benzylpenicillin (100 units $/ \mathrm{ml})$, streptomycin $(0.1 \mathrm{mg} / \mathrm{ml})$ (Gibco, Paisley, UK) at $37^{\circ} \mathrm{C}$ in humidified air containing $5 \% \mathrm{CO}_{2}$. Islets were cultured initially for $4 \mathrm{~h}$ in media containing $3.3 \mathrm{mmol} / \mathrm{l}$ glucose. Groups of 20 islets were selected and cultured for longer periods and in medium containing different secretagogues. To determine the time course of amyloid formation, islets were cultured in $11.1 \mathrm{mmol} / \mathrm{l}$ glucose for 2-12 days. To determine the effects of secretagogues, islets were cultured for 6 days in glucose $(4.2 \mathrm{mmol} / 1,11.1 \mathrm{mmol} / \mathrm{l}$ or $16.7 \mathrm{mmol} / \mathrm{l}$ ) or $3.3 \mathrm{mmol} / \mathrm{l}$ glucose with the following nonglucose secretagogues: $10 \mathrm{mmol} / \mathrm{l}$ leucine (Sigma, Poole, UK), $10 \mathrm{mmol} / \mathrm{l}$ leucine plus $100 \mathrm{mmol} / \mathrm{l}$ tolbutamide (Sigma) or $10 \mathrm{mmol} / \mathrm{l} \alpha$-ketoisocaproic acid (Sigma) plus $10 \mathrm{mmol} / \mathrm{l}$ glutamine (Sigma). Medium was replaced every two days and insulin and IAPP content of the media was measured by radioimmunoassay of each sample. At the end of the culture period the islets were fixed in $2.5 \%$ glutaraldehyde in $0.1 \mathrm{~mol} / 1$ sodium phosphate buffer ( $\mathrm{pH}$ 7.2) overnight. Specimens were post-fixed in $1 \%$ osmium tetroxide, dehydrated in ethanol and embedded in Spurr's resin (Taab Laboratories, Reading, UK). Ultrathin sections of the islets were mounted on nickel grids.

Radioimmunoassay. Samples of culture media were stored at $-20^{\circ} \mathrm{C}$. Insulin was measured in duplicate in a radioimmunoassay using a rat insulin standard (Pharmacia RIA-100, Pharmacia, Sweden). The minimum detectable concentration was 2.7 $\mathrm{pmol} / \mathrm{l}$ and the intra-assay coefficient of variation at $440 \mathrm{pmol} / \mathrm{l}$ was $3.2 \%$ and at $94 \mathrm{pmol} / 1$ was $3.9 \%$. Islet amyloid polypeptide was measured by radioimmunoassay using an assay based on Jamal et al [24] incorporating a human IAPP standard and ${ }^{125}$ I rat IAPP (Amersham, UK). The antibody used in this assay was generated in rabbits to human IAPP $_{1-37}$ and cross-reacted equally with hIAPP and mouse IAPP. The minimum detectable concentration was $5 \mathrm{pmol} / \mathrm{l}$ and the intra-assay $\mathrm{CV}$ was $16.3 \%$ at $10 \mathrm{pmol} / \mathrm{l}$ and $6.2 \%$, at $32 \mathrm{pmol} / \mathrm{l}$. The effects of secretagogues were examined over six days; IAPP or insulin content of media samples collected at days 2, 4 and 6 from the same islets were calculated as a mean to represent islet secretion under that experimental condition.

Quantitative electron microscopy. Ultrathin sections were immunogold labelled for IAPP with an antiserum against rat IAPP (Peninsula Laboratories, St. Helens, UK). The antisera 
was diluted 1:500 in phosphate buffered saline $\mathrm{pH} 7.4,0.1 \mathrm{~mol} / \mathrm{l}$ containing egg albumen (EA) (Sigma) $0.01 \%$ (PBS EA); this antisera cross-reacted with hIAPP (and mouse IAPP). After a 2-h incubation at room temperature, antisera-binding sites on the sections were identified by use of protein A gold $(15 \mathrm{~nm})$ (Biocell Laboratories, Cardiff, UK) (diluted 1/30 in PBS EA). Specificity was confirmed by loss of immunolabelling after preabsorption of diluted antisera with synthetic hIAPP $0.5 \mathrm{mg} / \mathrm{ml}$ ( $1 \mathrm{~h}$ at room temperature). Sections were washed in PBS EA followed by water and contrast was enhanced with uranyl acetate and lead citrate.

Electron-micrographic montages were prepared of an area of at least $10000 \mu \mathrm{m}^{2}$ from 3 randomly chosen islets/condition in each experiment. The experiment was repeated twice so that nine islets were examined and sectional areas quantified for each condition. The area occupied by abnormal accumulations of material immunogold-labelled for IAPP, was localised at high magnification and outlined on the lower magnification montages (see Fig. 2b): these IAPP-labelled accumulations were identified as either: (1) extracellular amyloid, characterised by a fibrillar appearance and clear localisation outside the cell; (2) intracellular fibrils of similiar dimensions localised in areas that were distinct from invaginations of the plasma membrane; or (3) amorphous extracellular IAPP-labelled material in which fibrils could not be easily identified. The montages were used to outline cellular islet tissue and IAPP-immunoreactive material in the form of accumulations or amyloid fibrils; areas of different features were calculated by use of an image analysis system (IBAS, Kontron, Germany) and their proportion in relation to cellular area (e.g. amyloid fibril area/cellular islet area) was calculated and expressed as a percentage. The effects of fibril formation on islet viability were assesssed by comparing survival of islets isolated from hIAPP transgenic and non-transgenic mice under different conditions and identification of cells showing visible signs of cellular damage; cells with one or more of the following changes - grossly vacuolated cytoplasm, disrupted mitochondria or condensed nuclear chromatin or all or any of these - were considered to show hallmarks of cellular damage or impending cell death or both. The proportion of cells with abnormal morphology in cultured transgenic mouse islets was compared with that in cultured non-transgenic islets and was assessed in relation to extracellular fibril content.

Statistics. Insulin and IAPP concentrations in the medium are presented as mean \pm SEM. Differences in secretion of IAPP and insulin at different time points or relative to secretion at $4.2 \mathrm{mmol} / 1$ glucose in 6-day cultures were compared by Mann Whitney U test. The proportion of extracellular fibrils in different culture conditions was compared by Mann-Whitney U test. Probability values of less than 0.05 were considered to be significant. The correlation between the degree of amyloidosis, (which is presented as means \pm SEM \% amyloid area/islet area) and (a) the IAPP and insulin content of the media and (b) the proportion of cells exhibiting signs of cell damage was assessed by use of the Spearmann Rank Correlation.

\section{Results}

Time course of peptide production and fibril formation. The hIAPP transgenic mouse islets cultured in the presence of $11.1 \mathrm{mmol} / \mathrm{l}$ glucose for up to 12 days were examined for amyloid fibril formation by electron microscopy at days $2,4,6$ and 12 of the culture a

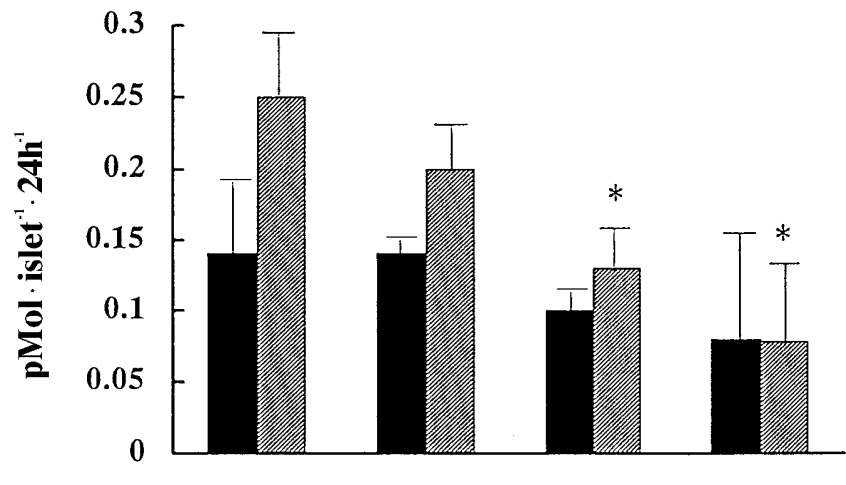

b

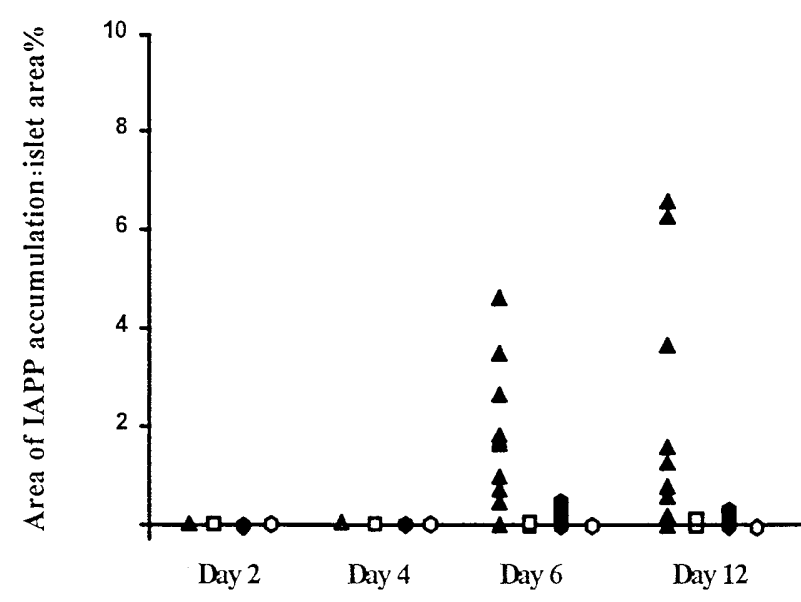

Duration of islet culture

Fig. 1a, b. Progressive changes in (a) insulin (hatched bars) and IAPP (solid bars) secretion and (b) amyloid fibril formation in hIAPP transgenic mouse islets cultured in $11.1 \mathrm{mmol} / \mathrm{l}$ glucose for 12 days. IAPP and insulin concentration in the media were reduced over this period; insulin concentration was reduced at day 6 and 12 compared with day $2(*, p<0.05)$ but the reduction in IAPP was not significantly changed. (b) No IAPP-immunoreactive amorphous ( $\boldsymbol{O}$ intracellular, extracellular) or fibrillar ( $\boldsymbol{\Delta}$ extracellular, $\square$ intracellular) material was detected until day 6 of culture when extracellular fibrillar deposits were more extensive than other forms $(p<0.05)$

period. Beta cells became increasingly degranulated (data not shown). Production of insulin progressively fell during this period and was lower on days 6 and 12 than on day $2(p<0.05)$ (Fig. 1). Islet amyloid polypeptide concentration in the media was more variable between experiments and although there was an apparent reduction in parallel with insulin, this change was not statistically significant (Fig.1a).

Transgenic mouse islets cultured for 2 or 4 days at $11.1 \mathrm{mmol} / \mathrm{l}$ glucose had IAPP immunoreactivity in beta-cell granules and some lysosomes; diffuse electron dense IAPP-immunoreactive material was present in the halo of some beta-cell granules (Fig.2a). No obvious morphological changes were seen adjacent to, or in, non-beta cells although IAPP-immu- 

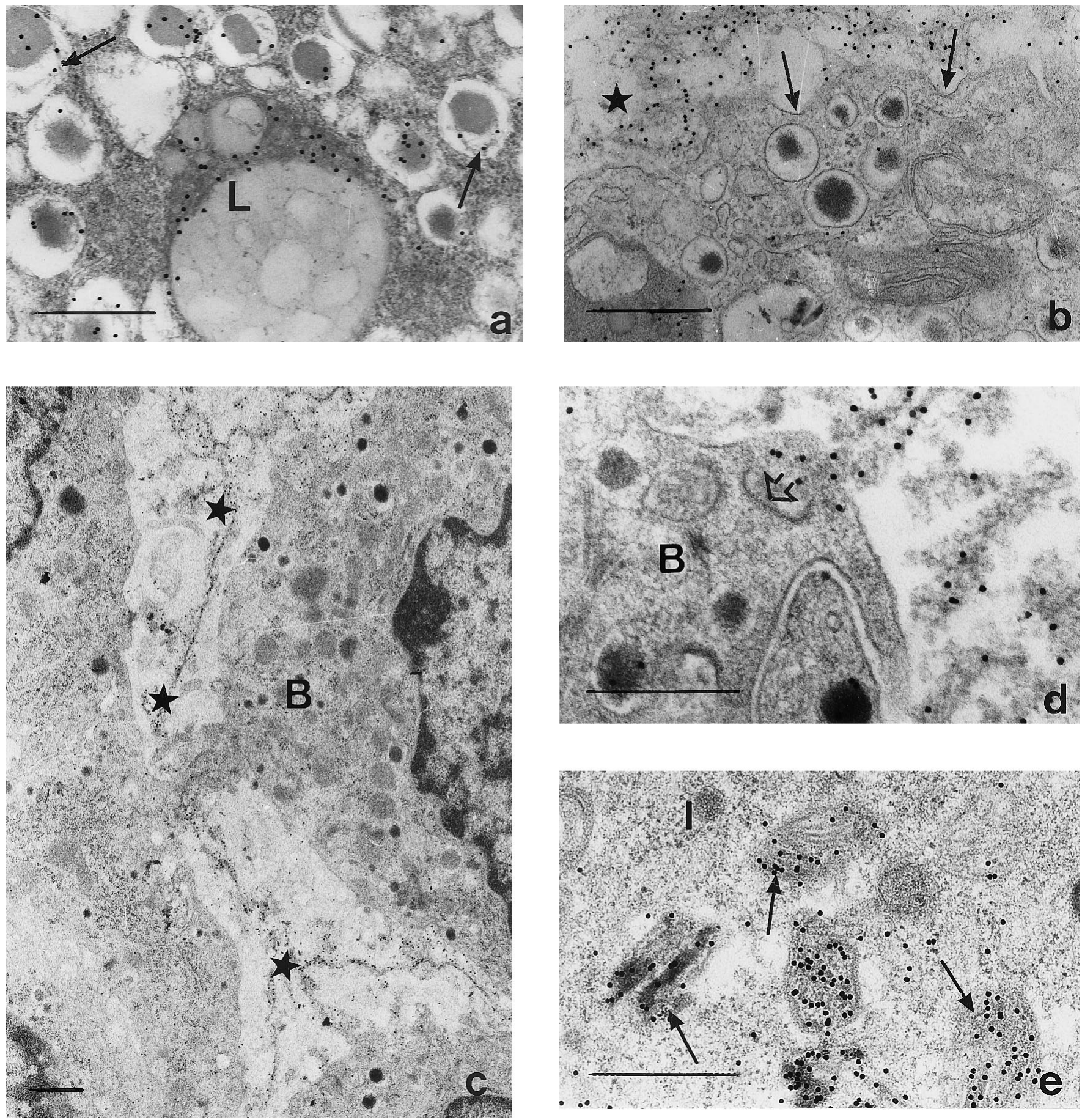

Fig. 2 a-e. IAPP-immunoreactive material in cultured TM islets. a IAPP-immunoreactivity was localised to insulin granules and some lysosomes in all TM islets; gold labelling was in the region of the insulin granule core but, in some granules, was over electron-dense filamentous material in the granule halo (arrows). IAPP-immunoreactivity was localised to electron-dense areas of lysosomes (L). b IAPP-immunoreactive fibrils (*) in extracellular spaces adjacent to a beta cell; fibrils were randomly arranged and some were positioned close to the beta-cell membrane and in membrane invaginations (arrows). The adjacent cell showed no evidence of cytotoxic changes in mitochondria (M) or other cellular organelles. c Extra-

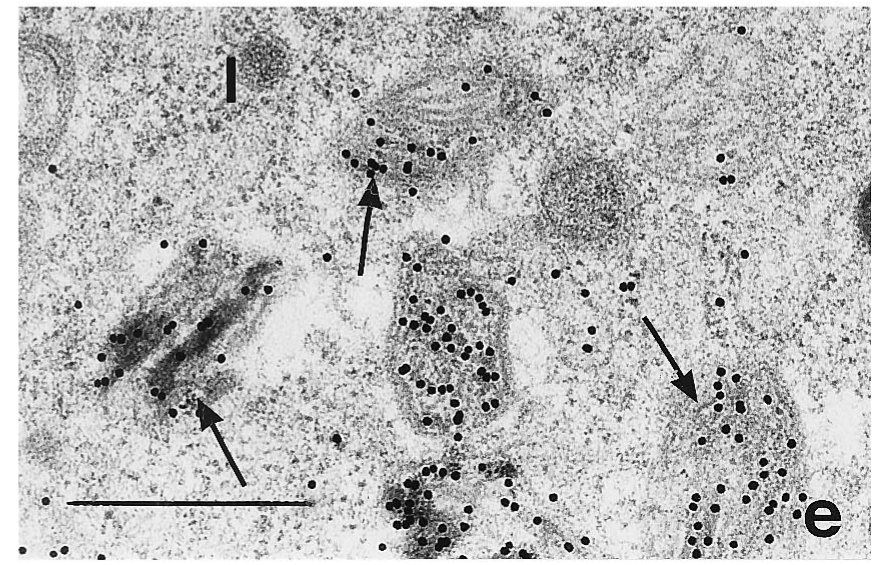

cellular fibrils formed in TM islet cultured for 6 days in $16.7 \mathrm{mmol} / \mathrm{l}$ glucose. IAPP-immunoreactive fibrils are present in extracellular spaces (*) adjacent to beta cells (B). d Amorphous extracellular IAPP-immunoreactive material (*) forming in membrane invaginations (arrows) of a beta cell (B) in an islet cultured with leucine. One area of the plasma membrane (arrowhead) has an apparently clathrin-coated endocytotic profile. e Intracellular IAPP-immunoreactive fibrils were usually in parallel alignment within unidentified organelles (arrow), insulin granule (I). Scale bars; a, b, c, $\mathrm{e}=0.5 \mu \mathrm{m}, \mathrm{d}=0.25 \mu \mathrm{m}$ 


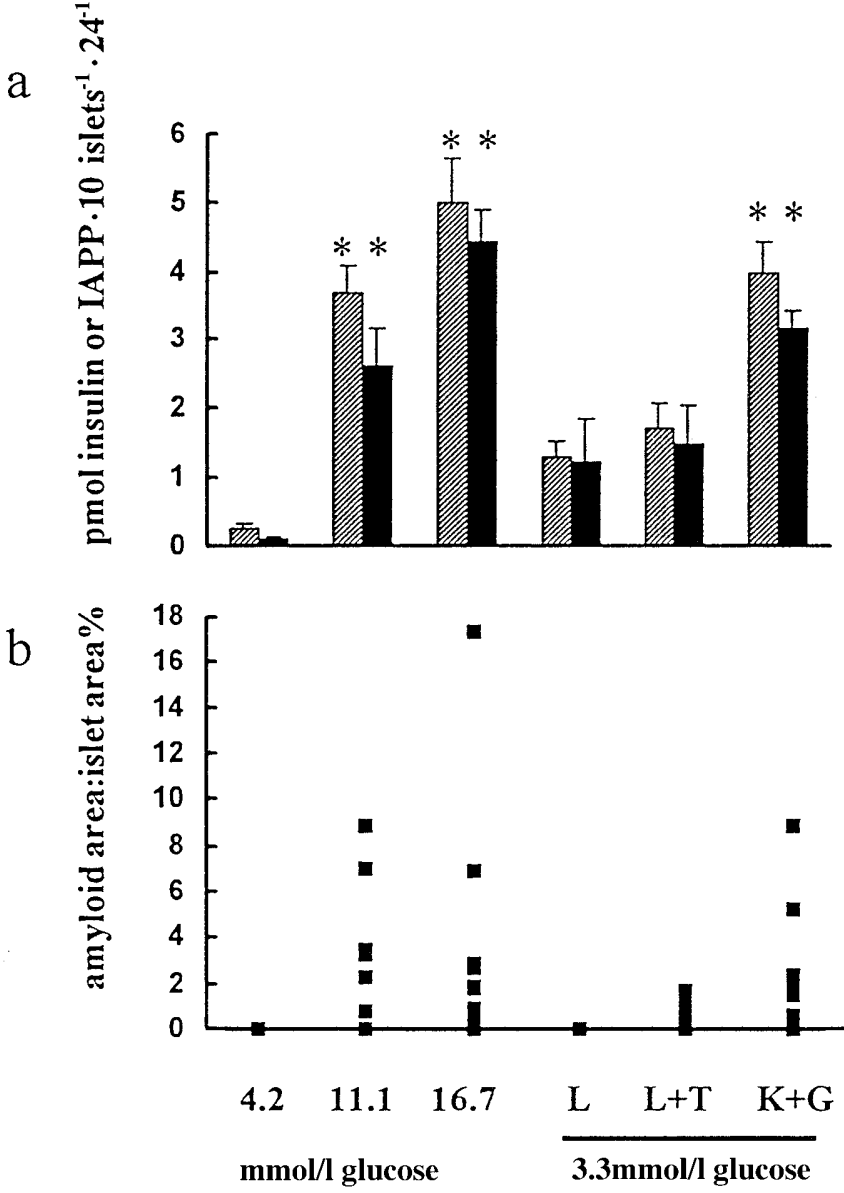

Fig. 3. a Comparison of insulin and IAPP production and amyloid formation in hIAPP TM islets cultured for 6 days with different secretagogues. a Concentrations of insulin (hatched bars) and IAPP (black bars) from islets cultured with $4.2 \mathrm{mmol} / 1, \quad 11.1 \mathrm{mmol} / 1, \quad 16.7 \mathrm{mmol} / 1$ glucose or with $3.3 \mathrm{mmol} / \mathrm{l}$ glucose plus $10 \mathrm{mmol} / \mathrm{l}$ Leucine (L), $10 \mathrm{mmol} / \mathrm{l} \mathrm{Leu-}$ cine and $0.1 \mathrm{mmol} / \mathrm{l}$ tolbutamide $(\mathrm{L}+\mathrm{T})$, or $10 \mathrm{mmol} / \mathrm{l} \alpha$-ketoisocaproic acid and $10 \mathrm{mmol} / \mathrm{l}$ glutamine $(\mathrm{K}+\mathrm{G})$. Concentrations are expressed as pmol insulin or IAPP secreted $\cdot 10$ islets . $24 \mathrm{~h}^{-1}$ (means $\pm \mathrm{SEM} ; n=3$ ). $* p<0.05$ compared with basal concentrations at $4.2 \mathrm{mmol} / \mathrm{l}$ glucose. b Quantification of the proportion of extracellular fibrils in the same islets expressed as amyloid fibril area:cellular islet area \% . Each symbol represents data from an islet. At least three islets were quantified per experimental condition ( $n=3$ experiments)

noreactivity was detectable in somatostatin-containing granules of delta-cells. At day 6 of culture, extracellular IAPP-immunoreactive fibrils were, however, visible in expanded intercellular spaces adjacent to islet beta cells (Fig. 2b, c) or, more infrequently, at the margin of cultured islets adjacent to beta cells. The border of the beta cell in close proximity to fibril deposits was not smooth as found in other regions but fibrils occupied irregular invaginations of the plasma membrane (Fig. 2b,). Fibrillar IAPP-immunoreactive material represented $1.11 \pm 0.35 \%$ (means \pm SEM) of the cellular islet area (Fig. 1b). Extracellular amorphous IAPP-immunoreactive material was present in some islets $(0.07 \pm 0.03 \%$ islet area $)$ at day 6 (Fig. 2d). Intracellular fibrils were found in very few cells at day 6 of culture (representing $0.002 \pm$ $0.001 \%$ islet area, Fig. 1 b); these fibrils were usually arranged in parallel arrays in well defined compartments of degranulated cells (see Fig. 2e). The degree of extracellular fibrillar deposits was similar at 6 $(1.11 \pm 3.5 \%)$ and 12 days $(2.38 \pm 0.8 \%$ islet area) (Fig. 1b). There was no change in the degree of amorphous IAPP-immunoreactive material with increased duration of culture but a 30-fold increase in the very small area occupied by intracellular fibrils at day 12 (mean $0.06 \pm 0.03 \%$ islet area) compared with day 6 $(0.002 \pm 0.001 \%)(p<0.05)$ (Fig. 1b).

Effects of glucose and non-glucose secretagogues on fibrillar amyloid formation. Insulin and IAPP concentrations in the culture media over a 6-day experimental period (Fig. 3a) were low (basal secretion) in the presence of $4.2 \mathrm{mmol} / \mathrm{l}$ glucose $(0.18 \pm 0.04$ and $0.10 \pm 0.02 \mathrm{pmol} \cdot 10$ islets $^{-1} \cdot 24 \mathrm{~h}^{-1}$, insulin and IAPP respectively) and statistically significantly increased in a dose-dependent manner for incubations with $11.1 \mathrm{mmol} / \mathrm{l}(3.4 \pm 0.5 \mathrm{pmol}$ insulin, $3.4 \pm 0.5$ IAPP) and $16.7 \mathrm{mmol} / \mathrm{l}$ glucose $(4.2 \pm 0.8 \mathrm{pmol}$ insulin, $4.3 \pm 0.8$ IAPP). Insulin and IAPP concentrations were increased but not statistically significantly so in the presence of leucine or leucine plus tolbutamide. Insulin and IAPP concentrations were greater $(p<0.05)$ than that found in basal conditions in the presence of $\alpha$-ketoisocaproic acid and glutamine (3.7 \pm 0.7 pmol insulin, $3.4 \pm 0.3$ pmol IAPP); these concentrations were similar to those found in the presence of $11.1 \mathrm{mmol} / \mathrm{l}$ glucose.

Extracellular fibrillar amyloid was quantified in islets cultured with different secretagogues (Fig. 3b). No fibrillar amyloid was found in islets cultured for 6 days in either $4.2 \mathrm{mmol} / \mathrm{l}$ glucose or leucine. The amount of fibrils was increased by culture with higher glucose concentrations: mean amyloid area/islet area was $3.1 \pm 1.8 \%$, in culture with $11.1 \mathrm{mmol} / 1$ glucose, $3.1 \pm 1 \%$ islet area in islets cultured in $16.7 \mathrm{mmol} / 1$ glucose. The proportion of amyloid was dependent upon the non-glucose secretagogue present in the culture; very little amyloid was present in islets cultured in leucine and addition of tolbutamide increased the fibrillar IAPP-immunoreactive material to $0.54 \pm$ $0.15 \%$ islet area. More extensive fibrils were present in islets culture in leucine and tolbutamide and in islets cultured with $\alpha$-ketoisocaproic acid and glutamine (Fig. 3 b). There was a positive correlation between the amounts of amyloid deposited under different culture conditions (amyloid area /islet area \%) and the concentrations of both IAPP $(r=0.5$, $p<0.05)$ and insulin $(r=0.55, p<0.05)$.

The morphology of the IAPP-immunoreactive accumulations was variable but could be related to the efficacy of the secretagogue. Under conditions of 


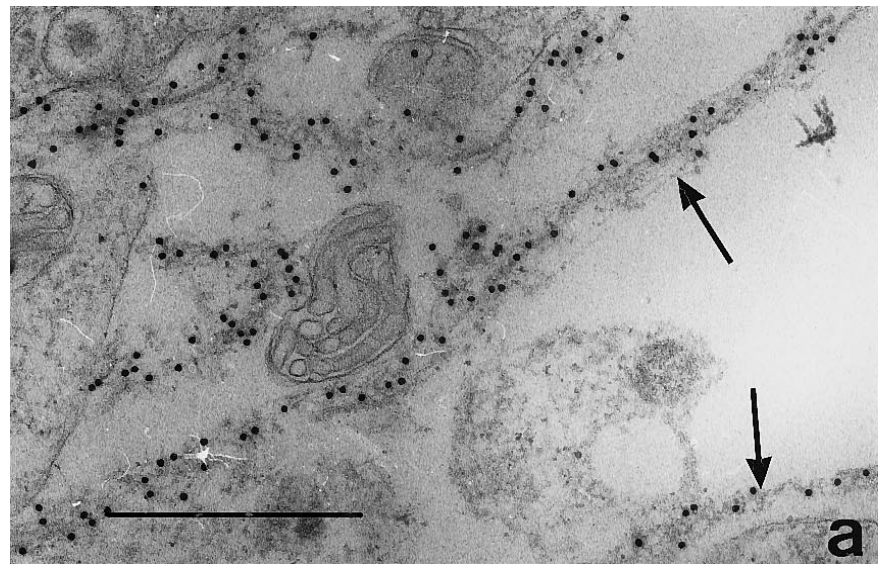

Fig. 4a, b. Extracellular IAPP fibrils: a Fibrils were present in parallel alignment forming twisted rope-like aggregates (arrows) in intercellular spaces. Islets cultured in $16.7 \mathrm{mmol} / \mathrm{l} \mathrm{glu}-$ cose; b Insulin granule cores were visible occasionally outside the cell as an exocytotic profile (arrow) adjacent to the extracellular amyloid $(\mathrm{A})$. Scale bars $=0.5 \mu \mathrm{m}$

higher stimulation $(16.7 \mathrm{mmol} / \mathrm{l}$ glucose $)$ extracellular fibrils appeared in both the random arrangement present in islets cultured at $11.1 \mathrm{mmol} / \mathrm{l}$ glucose (Fig. 2b, c) and in parallel alignment forming twisted rope-like aggregates (Fig. $4 \mathrm{a}$ ). Extracellular insulin granules were visible occasionally as exocytotic figures adjacent to the fibrillar mass (Fig.4b). Diffuse extracellular non-fibrillar IAPP-immunoreactive material was infrequently seen and was usually associated with low secretory conditions, e.g. after stimulation with leucine, but areas occupied by this material were not included in the quantification of fibrillar amyloid.

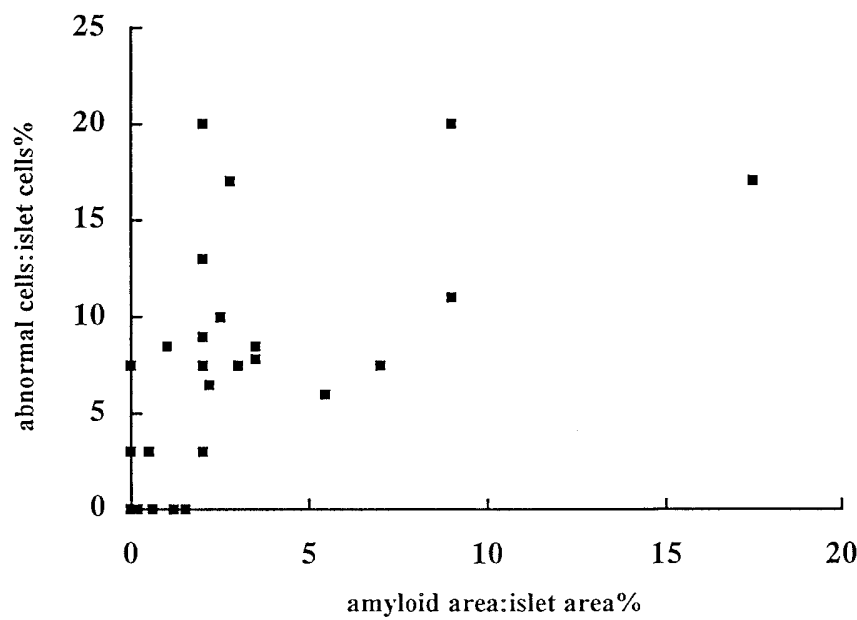

Fig.5. Correlation between the extent of islet amyloid and the proportion of cells with signs of cell damage in cultured TM islets. Each point represents data from one islet cultured as in Fig. 3

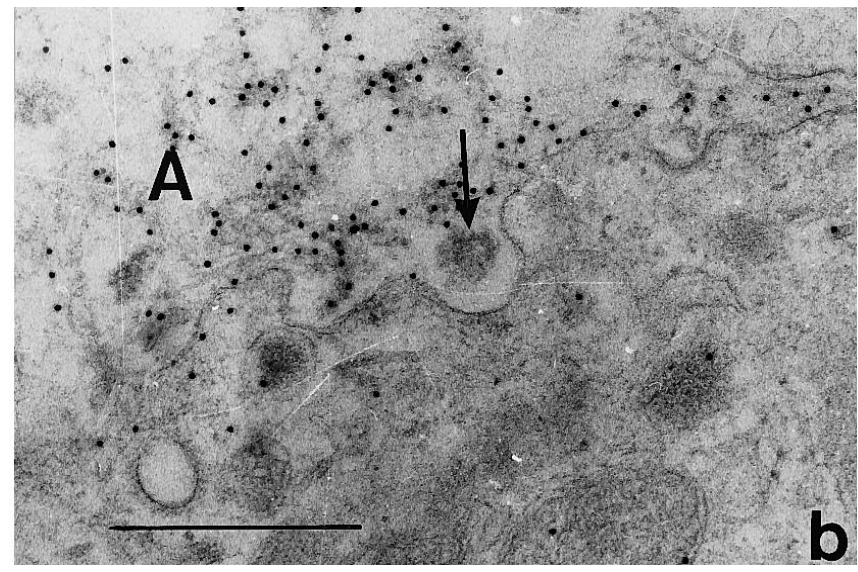

Effects of amyloid fibril formation on cell viability. Transgenic mouse islets were maintained in tissue culture in the presence of $11.1 \mathrm{mmol} / \mathrm{l}$ glucose for up to 12 days with no statistically significant reduction in islet number compared with non-transgenic islets incubated under the same conditions. The proportion of cells with evidence of cellular damage was less than $2 \%$ in non-transgenic islets and was $0-20 \%$ in transgenic islets. The proportion of cells with some degree of abnormal morphology correlated with the degree of extracellular fibrillar amyloid in the same islet $(r=0.8 ; p<0.0001)$ (Fig. 5).

\section{Discussion}

Deposition of amyloid is considered to be a progressive process often associated with conditions in which the concentration of the constituent protein is pathologically high. The physiological conditions that promote IAPP fibril formation in Type II diabetes are, however, not clear. Our data shows that IAPP fibril formation in $h I A P P$ TM isolated islets is progressive, largely extracellular and is related to the level of secretion of beta-cell products rather than to the specific concentration of glucose in the media. There is relatively little evidence of cell damage resulting from biosynthetic IAPP fibrils developing over 6 days compared with that reported for synthetic IAPP fibrils added to cultured cells [10] but there is evidence for some cytotoxic effects of amyloid deposition.

Islet amyloid polypeptide-immunoreactive accumulations in isolated TM islets were predominantly in the form of extracellular fibrils with the same dimensions as amyloid fibrils in islets of Type II diabetic patients $(5-10 \mathrm{~nm}$ in diameter and unbranching): fibrils were situated between endocrine cells and always adjacent to at least one beta-cell; exocytosed granules were occasionally visible at the cell membrane contiguous with the fibrils. These findings suggest that fibrils are formed at the site of beta-cell granule release which is between cells in mouse isolated islets [25]. Although polarised exocytosis of 
beta-cell granules towards a capillary border of the cell has been proposed [26], capillaries are not retained in isolated islets and there is no evidence for polarisation of granule release under these conditions. The relative absence of amyloid fibrils at the periphery of the islets suggests that fluid transfer is more efficient at the islet surface; the static fluid conditions in intercellular spaces in islets in tissue culture could promote accumulation of extracellular secreted peptide and thereby generate local high concentrations of human IAPP at neutral $\mathrm{pH}$, which are optimal conditions for fibril formation [27]. In primate diabetes, amyloid deposition in vivo is thought to be initiated at perivascular sites where the concentration of IAPP could be high due to passage of secreted peptide from many islet cells into the capillary [4]. Once established, these deposits are likely to form a barrier to diffusion of compounds between the islet and the circulation and further compromise clearance of secreted IAPP from inter-islet spaces.

The proportion of amyloid fibrils found within the cells was very low ( $<2 \%$ of the area occupied by extracellular fibrils) and they were present only in degranulated cells which showed no evidence of cytotoxic damage. Intracellular fibrils did not appear at an earlier time than extracellular fibrils ( 6 days culture in $11.1 \mathrm{mmol} / \mathrm{l}$ glucose). These data from isolated islets do not support the hypothesis that fibrillar islet amyloid is initiated at intracellular sites which becomes extracellular on cell death [8]. The isolated islet model does, however, enable detection and localisation of very early stages of fibril formation which is not possible in human or TM islets in vivo; it is possible that several mechanisms for the first stages of fibril formation could coexist within and outside the cell under different conditions in vivo and in vitro and more than one process could be involved in IAPP fibril formation. The organelles containing intracellular fibrils were not easily identifiable; these structures could represent dilated sacs of endoplasmic reticulum but were not lysosomes, some of which exhibit IAPP-immunoreactivity in beta cells of TM [21]. Synthetic proIAPP has been shown to form fibrils in vitro [28]; if this mechanism occurs in vivo, intracellular fibrils could be initiated at any point inside the cellular organelles involved with the pathway of synthesis and post-translational processing of the precursor peptide. Immunoreactivity for proIAPP fragments has been detected in some amyloid deposits [29] and it has been suggested that there is an increase in proIAPP intermediates in cultured human islets [30]; proIAPP fibrils either inside or outside the cells could act as an initiator for conversion of IAPP to beta conformation and fibril formation. The IAPPimmunoreactive material in beta-cell granules of TM has been described as fibrils [8,31]; if this represents some form of insoluble IAPP or proIAPP accumulation, this could act as a nidus for fibril formation [32] at the surface of the cell when the granule is released.

Extracellular amorphous IAPP-immunoreactive material was associated with low levels of secretion. Non-fibrillar material has been proposed to be a precursor for cerebral amyloid in Alzheimer's disease [33]. In islets, non-fibrillar IAPP appeared, however, at the same time point as fibrillar IAPP ( 6 days of culture) and there was no evidence of classical fibrils in this material. This type of IAPP aggregation, which may represent small oligomers, could occur at concentrations of secreted peptide which are too low to provide the conditions for fibril formation.

Glucose could have more than one role in islet amyloidosis. Firstly it acts as a potent beta-cell secretagogue increasing the amount of IAPP released. Secondly, glucose has been proposed to promote IAPP oligomerisation by glycation of monomeric IAPP and formation of advanced glycation end products (AGE). "Seeding" with AGE-modified IAPP has been shown to increase the rate of fibril formation from synthetic IAPP [34]. Very high glucose concentrations $(\sim 30 \mathrm{mmol} / \mathrm{l}-1 \mathrm{~mol} / \mathrm{l})$ over periods of months are, however, required to induce glycation or AGE formation of proteins in vitro $[34,35]$ and it is unlikely that monomeric IAPP secreted over a period of 6 days would become substantially glycated to contribute to the formation of amyloid in islets cultured at more physiological glucose concentrations. The use of non-glucose secretagogues enabled separation of these two effects of glucose in the cultured islets; leucine is a less effective secretagogue than its de-amination product, $\alpha$-ketoisocaproic acid in mouse islets [36] and few fibrils were found in islets cultured with leucine. Fibrils were, however, formed in the islets in the presence of the more effective secretagogues $\alpha$ ketoisocaproic acid plus glutamine and leucine and tolbutamide in the absence of increased glucose concentrations indicating that fibril formation is not induced solely by the presence of increased glucose. The stimulated release of IAPP and insulin under different conditions statistically significantly correlated with the extent of fibril formation. This indicated that a high concentration of secreted beta-cell components, however induced, was the primary determinant of the formation of fibrils and the amount of amyloid produced under these in vitro conditions.

Increased production or circulating concentrations of IAPP or both have also been proposed as contributory factors for islet amyloidosis in vivo. Obese insulin-resistant subjects have slightly increased circulating IAPP and insulin [37] and TM expressing hIAPP have plasma concentrations of IAPP of 37 to 333 $\mathrm{pmol} / \mathrm{l}$ compared with $10-103 \mathrm{pmol} / \mathrm{l}$ in non-transgenic mice $[6,7,8,22,38,39]$. Factors additional to IAPP concentrations are, however, required for amyloid formation in vivo in TM; an obese genetic back- 
ground or treatment to increase insulin resistance or both appears to be a prerequisite for fibril formation [40]. Recent studies in diabetic cats have shown more extensive islet amyloid in animals treated with sulphonyureas compared with those in which islet secretion was reduced by insulin therapy, providing further support for a role for increased beta-cell stimulation in islet amyloid formation [41]. These observations taken together suggest that increased beta-cell granule secretion is a prerequisite for, but cannot be the only factor involved in, islet amyloid formation.

Acknowledgements. We are grateful to the British Diabetic Association (D.L.A. MacArthur) and the Wellcome Trust (A. Clark) for financial support for this project. The Wellcome Trust provided the electron microscope in the Department of Human Anatomy and Genetics, Oxford. E.J.P. de Koning was the holder of a Medical Research Council Training Award (UK). We thank Y. Smart, P. Sutton, S. Chargé and D. Powell for their expert technical assistance.

\section{References}

1. Westermark P, Grimelius L (1973) The pancreatic islet cell in insular amyloidosis in human diabetic and non-diabetic islets. Acta Path Microbiol Scand, sect A, 81: 291-300

2. Clark A (1992) Islet amyloid: an enigma of Type II diabetes. Diabetes Metab Rev 8: 117-132

3. O'Brien TD, Hayden DW, Johnson KH, Fletcher TF (1986) Immunohistochemical morphometry of pancreatic endocrine cells in diabetic normoglycaemic glucose-intolerant and normal cats. J Comp Pathol 96: 357-369

4. de Koning EJP, Clark A, Bodkin N, Hansen BC (1993) Correlation of islet amyloid, reduced beta-cell mass with beta-cell function in diabetic monkeys. Diabetologia 36: 378-384

5. Schneider HM, Störkel S, Will W (1980) Das Amyloid der Langerhansschen Inseln und Seine Beziehung zum Diabetes Mellitus. Dtsch Med Wochenschr 105: 1143-1147

6. Janson J, Soeller WC, Roche PC, Nelson RT et al. (1996) Spontaneous diabetes mellitus in transgenic mice expressing human islet amyloid polypeptide. Proc Natl Acad Sci USA 93: 7283-7288

7. Soeller WC, Janson J, Emleigh-Hart S et al. (1998) Islet amyloid-associated diabetes in obese $\mathrm{A}^{\mathrm{vy} / \mathrm{a}}$ mice expressing human islet amyloid polypeptide. Diabetes 47: 734-750

8. Couce M, Kane LA, O'Brien TD et al. (1996) Treatment with growth hormone and dexamethasone in mice transgenic for human islet amyloid polypeptide causes islet amyloidosis and beta-cell dysfunction. Diabetes 45: 1094-1101

9. Verchere CB, D'Alessio DA, Palmiter RD et al. (1996) Islet amyloid formation associated with hyperglycaemia in transgenic mice with beta cell expression of human islet amyloid polypeptide. Proc Natl Acad Sci USA 93: 3492-3496

10. Lorenzo A, Razzaboni B, Weir GC, Yankner BA (1994) Pancreatic islet cell toxicity of amylin associated with Type II diabetes mellitus. Nature 368: 756-760

11. Clark A, Cooper GJS, Lewis CE et al. (1987) Islet amyloid formed from diabetes-associated peptide may be pathogenic in type-diabetes. Lancet ii: 231-234

12. Westermark P, Wernstedt C, Wilander E, Hayden DW, O'Brien TD, Johnson KH (1987) Amyloid fibrils in human insulinoma and islets of Langerhans of the diabetic cat are derived from a neuropeptide-like protein also present in normal islet cells. Proc Natl Acad Sci USA 84: 3881-3885

13. Clark A, Edwards CA, Ostle LR et al. (1989) Localisation of islet amyloid peptide in lipofuscin bodies and secretory granules of human $\beta$-cells and in islets of Type II diabetic subjects. Cell Tissue Res 257: 179-185

14. Kanatsuka A, Makino H, Ohsawa H et al. (1989) Secretion of islet amyloid polypeptide in response to glucose. FEBS Lett 259: 199-201

15. Kahn SE, D'Alessio DA, Schwartz MW et al. (1990) Evidence of cosecretion of islet amyloid polypeptide and insulin by beta-cells. Diabetes 39: 634-638

16. Johnson KH, O'Brien TD, Betsholtz C, Westermark P (1992) Islet amyloid polypeptide: mechanisms of amyloidogenesis in the pancreatic islets and potential roles in diabetes mellitus. Lab Invest 66: 522-535

17. Betzholtz C, Christmanson L, Engström U et al. (1990) Structure of cat islet amyloid polypeptide and identification of amino acid residues of potential significance for islet amyloid formation. Diabetes 39: 118-122

18. Westermark P (1972) Quantitative studies on amyloid in the islets of Langerhans. Ups J Med Sci 77: 91-94

19. Clark A, Wells CA, Buley ID et al. (1988) Islet amyloid, increased A-cells, reduced B-cells and exocrine fibrosis: quantitative changes in the pancreas in Type II diabetes. Diabetes Res 9: 151-160

20. Höppener JWM, Oosterwijk C, Niewenhuis MG et al. (1999) Extensive amyloid formation is induced by development of Type II diabetes mellitus and contributes to its progression: pathogenesis of diabetes in a mouse model. Diabetologia 42: 427-434

21. de Koning EJP, Morris ER, Hofhuis FMA et al. (1994) Intra- and extracellular amyloid fibrils are formed in cultured pancreatic islets of transgenic mice expressing human islet amyloid polypeptide. Proc Natl Acad Sci USA 91: 8467-8471

22. Höppener JWM, Verbeek JS, de Koning EJP et al. (1993) Chronic overproduction of islet amyloid polypeptide/amylin in transgenic mice: lysosomal localisation of human islet amyloid polypeptide and lack of marked hyperglycaemia or hyperinsulinaemia. Diabetologia 36: 1258-1265

23. Laird PW, Zijderveld A, Linders K, Rudnicki M, Jaenisch R, Berns A (1991) A simplified mammalian DNA isolation procedure. Nucleic Acids Res 19: 4293

24. Jamal H, Bretherton-Watt D, Suda K et al (1990) Islet amyloid polypeptide-like immunoreactivity (amylin) in rats treated with dexamethasone and streptozotocin. J Endocrinol 126: 425-429

25. MacArthur DLA, Badman MK, Morris JF, Clark A (1996) Insulin granule exocytosis occurs between endocrine cells in mouse isolated islets. Diabetologia 39 [Suppl 1] A76 (Abstract)

26. Bonner-Weir S (1988) Morphological evidence of pancreatic polarity of beta-cells within islets of Langerhans. Diabetes 37: 616-621

27. Chargé SBP, de Koning EJP, Clark A (1995) Effect of pH and insulin on fibrillogenesis of islet amyloid polypeptide in vitro. Biochemistry 34: 14588-14593

28. Hull RL, Jaikaran ETAS, Serpell LC, Fraser PE, Clark A, Landon M (1998) Synthetic human proislet amyloid polypeptide forms amyloid-like fibrils in vitro. Diabetologia 41 [Suppl 1] A168 (Abstract)

29. Westermark P, Engström U, Westermark GT, Johnson KH, Permert J, Betzholtz C (1989) Islet amyloid polypeptide (IAPP) and pro-IAPP immunoreactivity in human islets of Langerhans. Diabetes Res Clin Prac 7: 219-226 
30. Hou X, Ling Z, Quartier E et al. (1999) Prolonged exposure of pancreatic beta cells to raised glucose concentrations results in increased cellular content of islet amyloid polypeptide. Diabetologia 42: 188-194

31. Yagui K, Yamaguchi T, Kanatsuka A et al. (1995) Formation of islet amyloid fibrils in beta-secretory granules of transgenic mice expressing human islet amyloid polypeptide/amylin. Eur J Endocrinol 132: 487-496

32. Jarrett JT, Lansbury P (1993) Seeding "one-dimensional crystallization" of amyloid: a pathogenic mechanism in Alzheimer's disease and scrapie? Cell 73: 1055-1058

33. Joachim CL, Selkoe DJ (1992) The seminal role of $\beta$-amyloid in the pathogenesis of Alzheimer disease. Alzheimer Dis Assoc Disord 6: 7-34

34. Kapurniotu A, Bernhagen J, Greenfield N et al. (1998) Amyloidogenic properties of AGE-modified amylin: role in the amyloid deposition and islet cell dysfunction of Type II diabetes. Eur J Biochem 251: 208-216

35. Abdel-Wahab YH, O'Harte FP, Boyd AC, Barnett CR, Flatt PR (1997) Glycation of insulin results in reduced biological activity in mice. Acta Diabetol 34: 265-270

36. Stridsberg M, Sandler S, Wilander E (1993) Co-secretion of islet amyloid polypeptide (IAPP) and insulin from isolated rat pancreatic islets following stimulation or inhibition of beta-cell function. Reg Pept 45: 363-370

37. Enoki S, Mitsukaus T, Takemura J et al. (1992) Plasma islet amyloid polypeptide levels in obesity, impaired glucose intolerance and non-insulin dependent diabetes mellitus. Diabetes Res Clin Pract 15: 97-102

38. Verchere CB, D'Alessio DA, Kahn SE (1996) Consequences of human IAPP expression in transgenic mice. In: Shafrir E (ed) Lessons from animal diabetes, Vol 1. Birkhauser, Boston, pp 133-150

39. Fox N, Schrementi J, Masahiro N et al. (1993) Human islet amyloid polypeptide transgenic mice as a model of non-insulin dependent diabetes mellitus (NIDDM). FEBS Lett 323: 40-44

40. Kahn SE, Andrikopoulos S, Verchere CB (1999) Islet Amyloid: A long recognised but underappreciated pathological feature of Type II diabetes. Diabetes 48: 241-253

41. Hoenig M, O'Brien TD (1998) Glipizide administration leads to amyloidosis in a cat model of Type II diabetes. Diabetologia 14 [Suppl 1] A166 (Abstract) 